\title{
Studi Deskriptif Pelaksanaan Pembelajaran Aktif, Kreatif, Efektif, Dan Menyenangkan (PAKEM) Dalam Pembelajaran Tematik Di Madrasah Ibtidaiyah Al-Quraniyah Bengkulu Selatan
}

\author{
Cindy Waroka \\ Universitas Bengkulu \\ cindywaroka0@gmail.com \\ Sri Ken Kustianti \\ Universitas Bengkulu \\ srikenkustianti@gmail.com \\ Herman Lusa \\ Universitas Bengkulu \\ hermandatuk1005@gmail.com
}

\begin{abstract}
This study aims to describe the planning, implementation and assessment stages of the active, creative, effective, and fun learning approach (PAKEM) in Thematic learning at Madrasah Ibtidaiyah Al-Quraniyah, South Bengkulu. This research is a qualitative descriptive study. The subjects of this study were teachers of class IV / A at Madrasah Ibtidaiyah Al-Quraniyah Bengkulu Selatan. Data collection techniques used were observation, interviews, and documentation. Data were analyzed using data reduction steps, data display, and drawing conclusions. The research instruments used were observation guidelines, interview guidelines and documentation. The technique of checking the validity of the data was by using the triangulation technique. The results of this study are 1) The planning includes: (a) establishing a theme, (b) RPP identity, (c) determining core competencies / KI, basic competencies / KD, (d) formulating indicators, $(e)$ learning objectives, $(f)$ learning materials, ( $g$ ) approaches / methods, ( $h$ ) tools / media, (i) learning resources, $(j)$ assessment; 2) In the implementation of learning the teacher has implemented Thematic learning using the PAKEM approach properly, 3) the teacher has carried out an assessment of aspects of attitudes, aspects of knowledge and aspects of student skills. Based on the results of the research that has been done, it can be concluded that in the learning process the teacher has carried out the planning, implementation and evaluation stages of thematic learning by applying the PAKEM approach optimally and effectively.
\end{abstract}

Keywords: PAKEM approach, thematic learning

\section{Pendahuluan}

Berkaitan dengan tujuan abad ke-21 yaitu untuk menjawab tantangan zaman terhadap pendidikan, yakni untuk menghasilkan lulusan yang kompetitif, inovatif, 
kreatif, kolaboratif, serta berkarakter. Kurikulum 2013 adalah pembelajaran yang diorentasikan untuk menghasilkan insan yang produktif, kreatif, inovatif, dan afektif melalui pengutan sikap (tahu mengapa), keterampilan (tahu bagaimana), dan pengetahuan (tahu apa) yang terintegrasi. Pembelajaran dalam konteks kurikulum 2013 diarahkan untuk mendorong peserta didik mencari tahu bukan pembelajaran yang memberi tahu siswa. Pembelajaran yang bersifat mendorong siswa mencari tahu merupakan pembelajaran yang aktif dan konstruktif (Abidin : 2014).

Kurikulum 2013 menggunakan pembelajaran tematik yang menjadikan siswa berkemampuan yang komperhensif. Dalam pembelajaran tematik integratif ini, siswa belajar tema yang di dalam tema itu sudah mencakup seluruh mata pelajaran dan kompetensinya. Tema adalah pokok pemikiran atau gagasan pokok yang menjadi pokok pembicaraan. Tema inilah yang akan menjadi penggerak mata pelajaran lainnya dalam keutuhan proses pembelajaran. Pembelajaran Integratif dirancang sesuai dengan kapasitas fisik dan mental siswa termasuk kecenderungan gaya belajar setiap siswa. Kelebihan pembelajaran tematik yaitu dapat memberikan pengalaman yang bermakna, menyenangkan, hasil belajar dapat bertahan lama atau berkesan, mengembangkan keterampilan sosial, menumbuhkan sikap toleransi, komunikasi dan tanggap, serta menyajikan kegiatan yang bersifat nyata bagi siswa. Sehingga dalam menggunakan tematik integratif, guru harus bisa mengembangkan pembelajaran yang aktif, kreatif, inovatif, dan menyenangkan sesuai dengan lingkungan kehidupan keseharian siswa yang akan disajikan dalam proses pembelajaran (Ahmadi \& Amri, 2014 ) .

Proses pembelajaran di sekolah masih memiliki kelemahan diantaranya kurang menggali kompetensi siswa, kurang mengaktifkan siswa dalam pembelajaran, kurang memotivasi siswa untuk belajar dan kurang memanfaatkan media dan sumber belajar. Keberhasilan proses pembelajaran adalah interaksi edukatif, yakni interaksi anatara guru, siswa dan sumber belajar yang berfungsi untuk mengembangkan berbagai potensi yang dimiliki siswa dalam rangka membangun pengetahuan pada dirinya. Interaksi ini mampu membangun inspiratif, menyenangkan, menantang, memotivasi serta memberi ruang yang cukup bagi prakarsa, kreativitas, dan kemandirian sesuai bakat, minat, dan perkembangan fisik secara psikologis peserta didik. Proses interaksi edukatif berperan penting dalam upaya mewujudkan pembelajaran menjadi lebih berhasil dan berdaya guna (Yunus Abidin, 2014: 2 ).

Sementara itu, penelitian yang menggunakan pendekatan PAKEM, telah menunjukkan keberhasilan, diantaranya penelitian yang dilaksanakan oleh Novianingsih (2016) bahwa observasi yang dilakukan oleh peneliti dalam permasalahan proses pembelajaran adalah siswa terlihat kurang fokus saat pembelajaran berlangsung, siswa mengobrol dan menggangu saat proses pembelajaran, siswa terlihat mudah putus asa ketika menghadapi soal atau tugas yang sedikit sulit, tidak memperhatikan pembelajaran dengan baik sehingga materi yang dijelaskan tidak dapat mereka pahami, mengerjakan tugas asal-asalan dan kurang bersemangat saat belajar. Hal ini ditandai dengan adanya beberapa siswa yang memposisikan kepala di atas meja, dan beberapa siswa selalu meminta untuk segera istirahat atau pulang sekolah. Peneliti melakukan aktivitas tanya jawab, memberi kebebasan kepada siswa mengungkapkan pendapatnya, membuat produk hasil karya siswa dan diberi penghargaan atau reward, guru memfasilitasi media pembelajaran untuk memudahkan siswa memahami materi yang dipelajari supaya siswa tidak merasa bosan, menciptakan suasana pembelajaran yang nyaman serta tidak membuat siswa tertekan seperti belajar sambil bermain agar siswa semangat dalam proses pembelajaran. Sehingga berdasarkan data hasil penelitian dinyatakan bahwa pendekatan PAKEM dapat memberikan pengalaman bermakna kepada siswa ,sehingga apa yang diharapkan yaitu meningkatkan hasil belajar siswa dapat tercapai dengan baik.

Salah satunya untuk mewujudkan pembelajaran menjadi lebih berhasil dan berdaya guna yaitu menerapkan pendekatan pembelajaran yang tepat. Menurut 
pendapat Asmani (2011: 59), PAKEM merupakan sebuah pendekatan yang memungkinkan peserta didik mengerjakan kegiatan yang beragam untuk mengembangkan keterampilan, sikap, dan pemahamannya dengan penekanan belajar sambil bekerja. Sementara, guru memfasilitasi berbagai sumber dan alat bantu belajar termasuk pemanfaatan lingkungan supaya pembelajaran lebih menarik, mnyenangkan, dan efektif. PAKEM membantu siswa mengembangkan kemampuan berpikir tahap tinggi, berpikir kritis dan berpikir kreatif (critical dan creative thingking) (Jauhar, 2011: 1).

Madrasah Ibtidaiyah Al-Quraniyah merupakan salah satu sekolah swasta yang beralamatkan di Jalan Affan Bachsin Kabupaten Bengkulu Selatan. Madrasah Ibtidaiyah Al-Quraniyah memiliki keunggulan akademik maupun non-akademik. Memiliki guru dan siswa yang berprestasi. Berdasarkan pengamatan, guru disana telah menerapkan pembelajaran yang aktif, kreatif, efektif dan menyenangkan. Sehingga suasanya belajarnya menyenangkan dan siswanya aktif dalam pembelajaran. Di Madrasah Ibtidaiyah Al-Quraniyah sejak tahun 2013 telah menerapkan kurikulum 2013. Madrasah Ibtidaiyah Al-Quraniyah Bengkulu Selatan memiliki sarana dan prasarana yang memadai itu mendukung kegiatan pembelajaran, serta bahan dan sumber belajar yang cukup lengkap. Sehingga kegiatan pembelajaran yang menggunakan kurikulum 2013 dengan penerapan pembelajaran tematik ini dapat terealisasi dengan baik.

Berdasarkan realita yang telah dikemukakan, maka peneliti tertarik untuk melihat bagaimana proses pembelajaran tematik pada kompetensi guru dalam merencanakan, melaksanakan, dan mengevaluasi pembelajaran tematik dengan menerapkan pendekatan PAKEM yang dilakukan oleh guru kelas IV/A Madrasah Ibtidaiyah Al-Quraniyah Bengkulu Selatan. Untuk mengetahui hal tersebut, peneliti menggunakan jenis penelitian deskriptif.

Melalui studi deskriptif ini, peneliti bermaksud memaparkan dan menggambarkan lebih mendalam tentang penggunaan pendekatan PAKEM dalam pembelajaran tematik. Berdasarkan latar belakang tersebut, maka peneliti tertarik untuk mengambil judul "Studi Deskriptif Pelaksanaan Pembelajaran Aktif, Kreatif, Efektif, dan Menyenangkan (PAKEM) dalam Pembelajaran Tematik di Madrasah Ibtidaiyah Al- Quraniyah Bengkulu Selatan".

\section{Metode}

Jenis penelitian deskriptif kualitatif. Penelitian ini bertujuan untuk mendeskripsikan tahap perencanaan, pelaksanaan dan penilaian penggunaan pendekatan PAKEM dalam pembelajaran Tematik di Madrasah Ibtidaiyah AlQuraniyah Bengkulu Selatan. Peneliti bertindak sebagai non partisipan. Subjek penelitian ini adalah guru kelas IV/A Madrasah Ibtidaiyah Al-Quraniyah Bengkulu Selatan. Objek pada penelitian ini adalah tahap perencanaan, tahap pelaksanaan, dan tahap evaluasi pembelajaran dengan menggunakan pendekatan PAKEM. Instrumen penelitian adalah peneliti itu sendiri, dengan menggunakan pedoman observasi, pedoman wawancara dan dokumentasi. Teknik pengumpulan data yang digunakan adalah observasi, wawancara, dan dokumentasi. Data dianalisis menggunakan langkah- langkah reduksi data, display data, dan penarikan kesimpulan. Teknik pemeriksaan keabsahan data dengan menggunakan triangluasi teknik

\section{Hasil}

Berdasarkan hasil penelitian dan pembahasan mengenai judul penelitian studi deskriptif pelaksanaan pembelajaran aktif, kreatif, efekktif dan menyenangkan (PAKEM) dalam pembelajaran tematik di Madrasah Ibtidaiyah Al-Quraniyah Bengkulu Selatan diperoleh kesimpulan sebagai berikut: 
1. Perencanaan Pembelajaran

a. Pada tahap perencanaan pembelajaran, terdapat komponen-komponen yang lengkap, diantaranya:

1) Memilih dan menetapkan tema yaitu tema 3 subtema 1.

2) Membuat identitas RPP secara lengkap dimulai dari nama sekolah, kelas/semester, tema dan subtema, pembelajaran ke-, dan alokasi waktu.

3) Menganalisis SKL, Kompetensi Inti (KI) dan Kompetensi Dasar (KD)

4) Merumuskan indikator dari setiap $\mathrm{KD}$ dan dikembangkan dengan menggunakan KKO.

5) Merumuskan tujuan pembelajaran berdasarkan buku guru dan mengadung aspek ABCD yaitu Audience (siswa) Behavior (tingkah laku yang diharapkan selama proses pembelajaran), Condition (Aktivitas yang mengandung aktvitas PAKEM yaitu aktivitas mengalami, aktivitas interaksi, aktivitas komunikasi dan aktivitas refleksi), Degree (tingkat keberhasilan atau tingkat penampilan yang dapat diterima).

6) Materi pembelajaran diambil dari KD yang dikembangkan lagi dan disesuaikan dengan kebutuhan dan kemampuan siswa. Materi pembelajaran yang diajarkan yaitu tentang hak dan kewajiban terhadap tumbuhan, penafsiran bilangan desimal dan membuat kolase.

7) Menetapkan pendekatan/ metode yaitu pendekatan PAKEM, model pembelajaran Descovery Learning dan Metode pembelajaran yang digunakan yaitu pengamatan, tanya jawab, diskusi dan penugasan.

8) Menggunakan alat dan media pembelajaran yang mendukung dalam proses pembelajaran yaitu slide powe point, daun, ranting, gunting kertas sketsa gambar binatang dan lem.

9) Sumber pembelajaran yang digunakan yaitu buku guru, bku siswa dan lingkungan alam atau lingkungan di luar kelas.

10) Melakukan penilaian yaitu penilaian sikap yang melalui observasi, penilaian diri, penilaian antar siswa dan jurnal, penilaian pengetahuan yang melalui tes tulis, tes lisan sedangkan penilaian keterampilan melalui kinerja atau praktik, proyek dan potofolio.

2. Pelaksanaan Pembelajaran

a. Kegiatan pendahuluan sudah dilaksanakan melalui menyiapkan siswa, memberikan motivasi dan pertanyaan, melakukan apersepsi, menjelaskan tujuan pembelajaran, dan menyiapkan materi pembelajaran.

b. Kegiatan inti yang menggunakan pendekatan PAKEM. Semua komponen/ Kegiatan PAKEM ( mengalami, interaksi, komunikasi dan refleksi) telah dilakukan dalam kegiatan pembelajaran diantaranya:

1) Aktivitas mengalami : mengarahkan siswa mencari informasi yang luas tentang materi pembelajaran, menggunakan media pembelajaran dan sumber belajar dan melakukan percobaan.

2) Aktivitas interaksi : terjadinya interaksi antar siswa, guru dan sumber belajar, melibatkan siswa aktif dan demokratis dalam pembelajaran, membimbing siswa 
mengemukakan pendapat dalam teknik bertanya dan pemberian tugas dalam bentuk diskusi.

3) Aktivitas komunikasi : membiasakan siswa untuk membaca dan menulis tugas yang bermakna, memberikan kesemptan berpikir, menganalisis, dan menyelesaikan masalah dan bertindak tanpa rasa takut, mempresentasikan laporan, dan memajangkan hasil belajar siswa.

4) Aktivitas refleksi : mengecek kembali hasil laporan, memberi penguatann tentang materi/ tugas, dan siswa menyimpulkan materi.

c. Kegiatan penutup telah dilakukan mulai dari mengevaluasi pembelajaran yang telah berlangsung, menyimpulkan materi, memberikan umpan balik terhadap proses pembelajaran, memberikan $\mathrm{PR} /$ kegiatan tindak lanjut, dan menginformasikan kegiatan pembelajaran yang akan datang.

3. Evaluasi mencakup aspek kompetensi sikap, pengetahuan dan keterampilan. Instrumen penilaian sikap berdasarkan buku guru, dan terdapat rubrik penilaiannya yang bisa dinilai melalui observasi, penilaian diri, penilaian antar siswa ddan jurnal; instrumen penilaian pengetahuan dilaksanakan dengan memberikan nilai pada hasil latihan yang diberikan yang dinilai melalui tes tertulis dan tes lisan dan penugasan, untuk instrumen penilaian keterampilan dibuat secara terpisah dari penilaian pengetahuan dinilai melalui tes praktik, proyek dan portofolio.

\section{Pembahasan}

Berdasarkan analisis data yang diperoleh dari triangulasi pengumpulan data observasi, wawancara, dan dokumentasi yang telah dilakukan peneliti, maka diperoleh hasil sebagai berikut.

Guru menentukan tema berpedoman pada buku pegangan guru dan telah melakukan pengembangan materi atau penyesuaian konteks kedaerahan dalam pembelajaran. Guru harusnya dapat menentukan sendiri tema yang akan disampaikan dalam pembelajaran atau bisa juga dengan mengembangkan tema tersebut sehingga sesuai dengan kebutuhan dan karakteristik siswa.

Identitas rencana pelaksanaan pembelajaran (RPP) yang dibuat oleh guru terdiri dari nama sekolah, tema, subtema, pembelajaran ke, kelas/ semester, dan alokasi waktu. Identitas ini tergolong lengkap dalam membuat identitas RPP kurikulum 2013. Dalam RPP terdapat beberapa komponen, salah satu komponen penting dalam RPP yaitu identitas RPP. Menurut Abidin (2014: 299), identitas RPP merupakan ciri yang menunjukkan keterangan dari sebuah RPP yang dibuat oleh guru sesuai dengan komponen-komponen identitas RPP. Bagian identitas RPP minimalnya mencatumkan identitas sekolah, identitas mata pelajaran, atau tema/ subtema, untuk Sekolah Dasar, kelas/ semester, materi pokok, dan alokasi waktu

Dalam melakukan analisis Standar Kompetensi Lulusan , Kompetensi Inti, Kompetensi Dasar, dan membuat indikator, tidak dilakukan oleh gutu karena semuanya telah tercantum pada buku pegangan guru yang dirumuskan berdasarkan kurikulum. Kompetensi inti yang terdiri dari kompetensi inti 1 (KI 1) tentang sikap spiritual, kompetensi inti 2 (KI 2) tentang sikap sosial, kompetensi inti 3 (KI 3) tentang pengetahuan dan kompetensi inti 4 (KI 4) tentang keterampilan, kemudian diturunkan menjadi Kompetensi Dasar (KD). Dalam menentukan KD Ibu H sudah menentukan setiap KD berdasarkan KI yang ada dan sudah menentukan KD secara mandiri. Menurut Kemendikbud (2013), secara umum untuk setiap materi pokok terdapat empat KD sesuai dengan aspek KI. Guru harusnya menentukan KD berdasarkan semua KI, hal ini dikarenakan esensi dari kurikulum 2013 adalah keseimbangan antara sikap (sikap spiritual dan sosial), pengetahuan dan keterampilan. 
Setelah merumuskan setiap KD, guru menyusun indikator dari setiap KD tersebut. Guru merumuskan indikator berdasarkan KD sesuai dengan buku guru. Berdasarkan penelitian, guru merumuskan indikator secara mandiri, indikator yang sudah ada dalam buku guru dikembangkan lagi. Dalam merumuskan indikator pembelajaran, guru harusnya merumuskan semua KD menjadi indikator. Senada dengan pendapat Trianto (2009: 204).

Indikator dari setiap KD selanjutnya dirumuskan menjadi tujuan pembelajaran. Tujuan pembelajaran dirumuskan untuk mempermudah guru dalam menentukan langkah kegiatan pembelajaran yang akan dilaksanakan dan siswa memahami dan mengetahui apa yang harus dilakukan oleh siswa (Briggs dalam Soim, 2012).

Tujuan pembelajaran yang dirumuskan guru telah sesuai dengan KI, KD dan Indikatornya. Dalam merumuskan tujuan pembelajaran sudah mengandung empat aspek yaitu Audience, Behavior, Condition, dan Degree. Sependapat dengan pendapat Nofrion (2016: 149), bahwa seorang guru membuat tujuan pembelajaran yang pernyataannya mengandung empat komponen yang disingkat ABCD, yakni: (a) Audience (peserta didik); (b) Behavior (perilaku yang diharapkan); (c) Condition (Metode yang digunakan); dan (d) Degree (tingkatan pencapaian yang diharapkan).

Materi pembelajaran merupakan materi yang akan disampaikan dan digunakan untuk mencapai tujuan pembelajaran. Materi pembelajran yang digunakan guru berdasarkan pada buku guru dan buku siswa yang kemudian dikemas menjadi kegiatan pembelajaran. guru menyampaikan materi pembelajaran dengan berpedoman pada buku Tematik. Selain itu guru harusnya mampu mengembangkan materi pembelajaran sesuai dengan kondisi lingkungan siswa, kebutuhan dan karakteristik siswa.

Pendektan yang digunakan oleh guru dalam pembelajaran yaitu pendekatan PAKEM. Pendektan PAKEM lebih menekankan dalam pembelajaran suasana di dalam kelas diciptakan sedemikian rupa sehingga siswa aktif, kreatif, efektif, dan menyenangkan (Yayuk dkk, 2018: 114). Sementara metode yang digunakan oleh guru bervariasi, yakni ceramah, tanya jawab, diskusi, penugasan , demontrasi, dan eksperimen.

Guru menggunakan media pembelajaran berupa gambar, teks bacaan, majalah dan, bahan percobaan. Menurut Purwanti (2018), dalam penggunaan media pembelajaran tentu harus memenuhi aspek dan unsur-unsur yang bisa membuat proses pembelajaran semakin efektif. Guru harus mempertimbangkan beberapa hal, diantaranya (a) sesuai dengan tujuan yang akan dicapai, (b) karakteristik media yang akan digunakan, (c) mendukung isi dan bahan pembelajaran, (d) mudah diperoleh, (e) mudah diakses, (f) tidak memakan waktu yang lama, (g) efektifitas penggunaan media dalam pembelajaran.

Dalam menyusun langkah pembelajaran, guru menyusun langkah pembelajaran mulai dari kegiatan pendahuluan, kegiatan inti dan kegiatan penutup. Menurut Sarinah (2015: 175), langkah-langkah kegiatan pembelajaran memuat unsur kegiatan pendahuluan/ pembuka, kegiatan inti, dan kegiatan penutup. Guru menggunakan pendekatan PAKEM , maka pada kegiatan inti dimasukkan tahap kegiatan PAKEM (Mengalami, Interksi, Komunikasi, Refleksi).

Penilaian yang dilakukan oleh guru pada kegiatan pembelajaran berupa penilaian aspek sikap dan observasi. Penilaian sikap dilaksanakan berdasarkan rubrik penilaian yang terdapat di buku guru. Penilaian pengetahuan dengan tes tertulis dan aspek pengetahuan dengan penilaian kerja. Kemendikbud (2013) menjelaskan bahwa pendidik melakukan penilaian kompetensi sikap melalui observasi, penilaian diri, penilaian "teman sejawat" (peer evaluation) dan jurnal. Kemudian kompetensi pengetahuan melalui tes tertulis, tes lisan, dan penugasan. Instrumen tes tulis berupa soal pilihan ganda, isian ,jawaban singkat, benar-salah, menjodohkan, dan uraian. Selanjutnya kompetensi keterampilan melalui penialaian kinerja, yaitu penilaian yang menuntut siswa mendemonstrasikan suatu kompetensi tertentu dengan menggunakan tes praktik, proyek, dan penilaian portofolio. 
Tahap pelaksanaan merupakan proses yang memberikan keputusan bahwa kegiatan pembelajaran telah memiliki sumber daya manusia dan sarana serta prasarana yang diperlukan sehingga dapat membentuk kompetensi dan mencapai tujuan yang diinginkan. Pelaksanaan sering juga disebut implementasi. Senada dengan pendapat Suci, dkk (2020:14).

Berdasarkan hasil analisis data yang didapatkan dari triangulasi pengumpulan data observasi, wawancara, dan dokumentasi yang dilakukan oleh peneliti, maka didapatkan hasil sebagai berikut: Tahap pelaksanaan pembelajaran yang dilakukan oleh guru sudah sesuai dengan petunjuk kegiatan pembelajaran yaitu kegiatan pendahuluan, kegiatan inti, dan kegiatan penutup. Dalam kegiatan pendahuluan Ibu $\mathrm{H}$ sudah menyiapkan siswa dengan cara berbaris sebelum masuk kelas, berdoa dan dilanjutkan membaca Al-Qur'an atau membaca surat pendek AlQur'an. Selanjutya guru mengecek kehadiran serta meminta siswa menyiapkan perlengkapan belajar masing-masing. Menurut Habibati (2017 :46 ), tujuan menyiapkan siswa untuk menyiapkan mental siswa sehingga siswa dapat fokus mengikuti keseluruhan proses pembelajaran sehingga suasana belajar menjadi menyenangkan.

Memotivasi siswa pada awal kegiatan pembelajaran akan memberikan dorongan dan semangat siswa dalam mengikuti proses pembelajaran. Guru sudah memotivasi siswa pada awal kegiatan pembelajaran dengan mengajak bernyanyi dan bercerita. Mengingat pentingnya memotivasi siswa dalam belajar, sehingga setiap guru harusnya berusaha untuk selalu memunculkan motivasi siswa dari awal kegiatan pembelajaran. Hal ini senada dengan pendapat Sumarsono, dkk (2020:47), bahwa manfaat motivasi siswa yaitu membangkitkan dan meningkatkan semangat belajar pada siswa untuk belajar sampai berhasil.

Apersepsi sebagai adalah kegiatan yang mengaitkan pengalaman atau mengajukan pertanyaan tentag pembelajaran yang pernah siswa alami akan memudahkan siswa memahami pembelajaran yang akan dipelajari. Dalam kegiatan pembelajaran yang dilakukan, guru telah melakukan apersepsi dengan meminta siswa dengan tepuk dan menyanyikan mars PPK, kemudian siswa mengamati gambar pada buku siswa, kemudaian bertanya kepada siswa mengenai pengalaman yang pernah dialami sebagai materi selanjutnya.

Selanjutnya guru menyampaikan tujuan pembelajaran secara lisan. Tujuan pembelajaran tidak jarang terabaikan disampaikan kepada siswa yang berakibat pengetahuan mereka mengambang, siswa dapat memahami yang materi yang disampaikan oleh guru namun kurang bisa aplikatif terhadap materi itu sendiri. Menurut Octavia (2020:74), siswa perlu mengetahui dengan jelas mengapa mereka berpartisipasi dalam suatu pembelajaran tersebut, tujuan pembelajaran disampaikan kepada siswa dimaksudkan untuk menarik perhatian dan minat siswa untuk mengahadapi pelajaran yang akan dilakukan

Kegiatan inti terdapat pada tahap pelaksanaan pembelajaran menggunakan pendekatan PAKEM sehingga dalam langkah pembelajaran dimasukkan komponen (kegiatan) PAKEM. Kegiatan PAKEM yang dimaksud yaitu mengalami, interaksi, komunikasi dan refleksi.

Kegiatan mengalami yang dilakukan oleh guru dengan cara meminta siswa untuk mencari informasi seluas-luasnya tentang materi yang akan dipelajari, dengan cara membaca buku, mengamati, wawancara atau diskusi dengan teman sebangku dan, dan mencari dengan sumber lain. Menurut Asmani (2011: 123-124) dalam hal mengalami, siswa belajar banyak melalui berbuat dan pengalaman langsung dengan mengaktifkan banyak indra. Beberapa contoh dari kegiatan mengalami yaitu melakukan pengamatan, percobaan, penyelidikan, dan wawancara. Kegiatan mengalami ini membuat siswa dapat merasakan teori dan ide-ide progresif. guru menggunakan media pembelajaran seperti gambar dan anak dapat mengamati gambar tersebut, dan anak juga melakukan percobaan seperti membuat kolase kupu-kupu dari bahan lingkungan alam. 
Kegiatan interaksi guru lakukan dengan cara mempersilahkan siswa untuk berinteraksi kepada teman, guru, lingkungan dan sumber belajar. Menurut Asmani (2011: 124), kegiatan interaksi kegiatan pembelajaran yang menjadikan suasana lebih hidup dan menarik, kesalahn makna berpeluang terkoreksi, makna yang terbangun semakin mantap dan kualitas hasil belajar akan meningkat. Kegiatan interaksi memberikan peluang bagi siswa untuk berekspresi dan berartikulasi sesuai kemampuan siswa masing-masing individu.

Guru merangsang siswa untuk bertanya . Guru meminta siswa menyusun pertanyaan berdasarkan hasil dari kegiatan mengalami sementara siswa lainnya memberikan tanggapan sehingga suasana kelas menjadi aktif dan kondusif. Siswa memberikan tanggapan langsung mengacungkan jari dan menanggapi pertanyaan tersebut. Banyak siswa yang mengajukan pertanyaan ataupun menanggapi pertanyaan, guru memberikan penghargaan kepada mereka baik tepuk tangan ataupun kata-kata pujian seperti "baik, benar, bagus dan hebat".

Guru memberikan perhatian kepada siswa yang bertanya dengan meminta siswa lain memperlihatkan temannya, lalu memberikan masukan atau mengarahkan pertanyaan tersebut, kemudian meminta siswa untuk menanggapinya. Selanjutnya guru memberikan penghargaan kepada siswa yang bernai bertanya ataupun menanggapi pertanyaan. Karena dengan memberikan penghargaan kepada siswa akan memberikan motivasi belajar atau menumbuhkan semangat belajar siswa.

Kegiatan komunikasi guru lakukan yaitu memberikan waktu siswa untuk berpikir, menganalisis dan menyelesaikan masalah supaya jawaban yang didapatkan sesuai yang dibutuhkan dan guru meminta siswa untuk menulis laporan individu maupun kelompok yang akan dipresentasikan nantinya jika waktunya sudah selesai. Sehingga laporan tersebut akan dipajangkan di depan kelas. Guru memajangkan hasil belajar siswa seperti memajangkan hasil kolase kupu-kupu yang dibuat oleh siswa sesuai petunjuk yang diberikan guru, sehingga pembelajaran menjadi meyenangkan.

Selanjutnya kegiatan refleksi yang dilakukan oleh guru yaitu meminta siswa untuk mengecek kembali laporan yang telah dibuat supaya tidak terdapat kesalahan dapat pengkoreksian. Kemudian guru memberikan penguatan materi yang bertujuan untuk memberi kejelasan kepada siswa tentang materi atau jawaban, sehingga siswa lebih memahami dan mengerti. Dan kegiatan inti terakhir dalam kegiatan refleksi yaitu guru membimbing siswa untuk menyimpulkan materi yang telah dilakukan. Kegaitan refleksi menjadikan wahana evaluasi dari strategi yang sudah diterapkan dan hasil yang didapatkan. Refleksi dapat memberikan peluang untuk memunculkan gagasan baru yang bermanfaat dalam perbaikan makna hasil pembelajaran.

Selanjutya kegiatan penutup dalam pembelajaran tematik dilakukan dengan cara menyimpulkan kegiatan pembelajaran yang telah dilaksanakan secara bersama-sama. Guru memberikan kesimpulan dan penekanan materi tertentu yang dianggap sangat penting bagi siswa pahami dan ketahui. Kegiatan menyimpulkan sebaiknya dilakukan siswa dibawah bimbingan guru sehingga mendapatkan kesimpulan materi yang pas dan lengkap.

Berdasarkan hasil penelitian, guru melakukan evaluasi pembelajaran dengan cara meminta siswa untuk mengerjakan soal uraian di buku siswa. Guru hendaknya menyusun instrumen tes tertulis secara mandiri. Instrumen yang disusun guru dapat mengukur pencapaian KD berdasarkan KI 3 dan KI 4 yang berada pada level 1, 2, dan 3. Menurut Kemendikbud (2013), pendidik menilai kompetensi pengetahuan melalui tes tertulis, tes lisan, dan penugasan. Instrumen tes tertulis berupa soal pilihan ganda, isian, jawaban singkat, benar-salah, menjodohkan, dan uraian. Instrumen tes lisan berupa daftar pertanyaan, dan instrumen penugasan berupa PR atau proyek yang dikerjakan secara individu atau kelompok sesuai dengan karakteristik tugas. 
Setelah selesai evaluasi, guru memberikan umpan balik berupa pujian yang pada umumnya disukai siswa. Menurut Setiawan (2018: 284), umpan balik merupakan elemen kunci pada penilaian formatif. Pemberian umpan balik memberitahukan keterampilan fisik, pengetahuan maupun sikap yang benar akan meningkatkan kepuasan siswa terhadap kinerja mereka. Pemberian umpan balik dapat juga didefinisikan sebagai informasi yang diberikan oleh guru agar siswa dapat secara lebih baik dalam menunjukkan kinerja aktual.

Tahap evaluasi sering digambarkan sebagai penilaian atas perkembangan siswa karena berfokus pada kemampuan siswa dalam belajar. Penilaian mampu menggambarkan sikap, keterampilan dan pengetahuan apa saja yang sudah atau belum dimiliki oleh siswa dan sebagainya.

Dalam melaksanakan penilaian aspek sikap, pengetahuan dan keterampilan, guru melakukan penilaian pengetahuan diakhir pembelajaran, dan penilaian keterampilan dilakukan selama proses pembelajaran berlangsung. Sedangkan penilaian sikap, guru lakukan dengan cara observasi terhadap kegiatan yang dilakukan oleh siswa. Dalam proses pembelajaran, siswa melakukan bermacam kegiatan yang akan terlihat sikap yang ditunjukkannya, baik sikap saat berbicara, cara menyampaikan pendapat, mengerjakan tugas, berinteraksi bersama teman ataupun guru. Observasi dilakukan selama prose pembelajaran berlangsung dengan memuat catatan-catatan kecil.

Berdasarkan pendapat di atas dapat dideskripsikan sebgai berikut; observasi dilakukan secara berkesinambungan dengan menggunakan alat indra, baik secara langsung maupun tidak langsung dengan menggunakan pedoman observasi; penilaian diri dilakukan dengan cara meminta siswa untuk menjelaskan kelebihan dan kekurangan dirinya dalam konteks pencapaian kompetensi; penilaian "teman sejawat" (peer evaluation) dilakukan dengan cara meminta siswa untuk saling menilai terkait dengan pecapaian kompetensi; sedangkan jurnal dilakukan dengan cara membuat catatan pendidik di dalam dan di luar kelas yang berisi informasi hasil observasi atau pengamatan tentang kekuatan dan kelemahan siswa yang berkaitan dengan sikap dan perilaku.

Berdasarkan hasil penelitian, guru melakukan penilaian kompetensi pengetahuan dengan tes tertulis, tes lisan dan penugasan. guru menyusun instrumen tes tertulis secara mandiri yang disusun untuk dapat mengukur pencapaian kompetensi dasar berdasarkan KI 3 dan KI 4. Berdasarkan Standar Penilaian, yang tertera dalam Permendikbud No. 66 Tahun 2013 dikemukakan bahwa pendidik menilai kompetensi pengetahuan melalui tes tulis, lisan dan penugasan.

Penilaian keterampilan yang dilakukan guru yaitu melalui kinerja yang disebut dengan penilaian praktik. guru melakukan penilaian keterampilan dengan menggunakan rubrik penilaian kinerja berdasarkan pedoman yang ada. Berdasarkan Standar Penilaian, yang tertera dalam Permendikbud No. 66 Tahun 2013 dijelaskan pendidik menilai kompetensi keterampilan melalui penilaian kinerja yaitu penilaian yang menunt siswa mendemostrasikan suatu kompetensi dengan menggunakan tes praktik, projek, dan penilaian portofolio.

Berdasarkan uraian di atas dapat disimpulkan sebagai berikut; tes praktik merupakan penilaian yang menuntut respon berupa keterampilan melakukan aktivitas sesuai dengan tuntutan kompetensi; projek merupakan tugas-tugas belajar yang meliputi kegiatan perancangan, pelaksanaan, dan pelaporan secara tulis maupun lisan dalam waktu tertentu; dan penilaian portoflio merupakan penilaian yang dilakukan untuk menilai kumpulan seluruh karya siswa dalam bidang tertentu yang besifat untuk mengetahui minat, perkembangan, prestasi siswa dalam kurun waktu tertentu.

\section{SIMPULAN}


Berdasarkan hasil penelitian dan pembahasan mengenai studi deskriptif pelaksanaan pembelajaran aktif, kreatif, efektif dan menyenangkan (PAKEM) dalam pembelajaran Tematik di Madrasah Ibtidaiyah Al-Quraniyah Bengkulu Selatan. Guru kelas IV/A Madrasah Ibtidaiyah Bengkulu Selatan sudah menggunakan pendekatan PAKEM dalam proses pembelajaran dengan baik dan runtut. Dan dapat disimpulkan bahwa dalam proses pembelajaran dengan menggunakan pendekatan PAKEM dapat membuat anak lebih aktif, kreatif, efektif dan menyenangkan. Sehingga pelaksanaan pembelajran lebih kondusif, meyenangkan dan bermakna untuk siswa.

\section{SARAN}

Berdasarkan kesimpulan penelitian dengan judul stidi deskriptif pelaksanaan pembelajaran aktif, kreatif, efektif, dan menyenangkan (PAKEM) dalam pembelajaran tematik di Madrasah Ibtidaiyah Al-Quraniyah Bengkulu Selatan maka disarankan pada guru untuk memperbaiki beberapa hal sebagai berikut:

1. Untuk tahap perencanaan, hendaknya guru dalam menyusun perencanaan pembelajaran pada RPP untuk melengkapi komponen-komponen yang termuat dalam RPP dan mempersiapkan media pembelajaran yang lebih menarik dan bervariasi.

2. Dalam tahap pelaksanaan, hendaknya keempat kompenen aktivitas dalam pendekatan PAKEM yaitu aktivitas mengalami, aktivitas komunikasi, aktivitas interaksi dan akitivitas refleksi harus ditetapkan dalam setiap proses pembelajaran lebih maksimal lagi, supaya yang dilakukan dalam pembelajaran Tematik tersebut benar-benar menggunakan pendekatan PAKEM yang optimal.

3. Dalam tahap Evaluasi, dalam penilaian sikap siswa hendaknya guru mengamati sikap kepedulian siswa terhadap lingkungan dengan baik karena sikap ini harus diamati oleh guru saat siswa berada di luar kelas.

\section{Referensi}

Abidin, Y., (2014). Desain Sistem Pembelajaran dalam Konteks Kurikulum 2013. Bandung: PT Refika Aditama.

Ahmadi, I, K., \& Amri, S., (2014). Pengembangan \& Model pembeljaran Tematik Integratif. Jakarta: Prestasi Pustaka.

Asmani, J, M., (2011). 7 Tips Aplikasi PAKEM. Jakarta: Diva Press.

Habibati., (2017). Strategi Belajar Mengajar. Banda Aceh: Syaiah Kuala University Press.

Jauhar, M., (2011). Implementasi PAIKEM dari Behavioristik sampai Konstruktivistik. Jakarta: Prestasi Pustakarya.

Marwiyah, dkk., (2018). Perencanaan Pembelajaran Kontemporer Berbasis Penerapan Kurikulum 2013. Yogyakarta: CV. Budi Utama.

Nofrion., (2016). Komunikasi Pendidikan. Jakarta: Kencana.

Oktaria, S., (2020). Model-model Pembelajaran. Yogyakarata: CV. Budi Utama.

Sarinah., (2015). Pengantar Kurikulum. Yogyakarta: CV. Budi Utama.

Setiawan, D, F., (2018). Prosedur Evaluasi Dalam Pembelajaran. Yogyakarta: CV. Budi Utama.

Purwanti, P., 2018. 10 Kriteria dalam Menentukan Media Pembelajaran Yang Tepat. (https://pakarkomunikasi.com/kriteria-dalam-menentukan-mediapembelajaran)

Soim, Ibnu. 2012. Perumusan Indikator Dan Tujuan Pembelajaran. (http:// Perumusan Indikator Dan Tujuan Pembelajaran.soim.html)

Suci, dkk., 2020 . Administrasi Kegiatan Belajar. (http://books.google.co.id/) 